\title{
Toxic multinodular goitre: a surprising finding
}

\author{
Marlene Rodrigues, ${ }^{1}$ Helena Ferreira, ${ }^{2}$ Ana Antunes, ${ }^{1,3}$ Olinda Marques ${ }^{3,4}$
}

${ }^{1}$ Department of Pediatrics, Hospital de Braga, Braga, Portugal

${ }^{2}$ Department of Pediatrics, Hospital da Senhora da Oliveira Guimaraes EPE, Guimaraes, Portugal

${ }^{3}$ Pediatric Endocrinology Unit, Hospital de Braga, Braga, Portugal

${ }^{4}$ Department of Endocrinology, Hospital de Braga, Braga, Portugal

\section{Correspondence to}

Dr Marlene Rodrigues, rodrigues.f.marlene@gmail.com

Accepted 3 September 2017

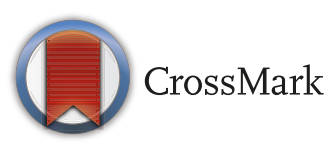

To cite: Rodrigues $M$, Ferreira $\mathrm{H}$, Antunes $\mathrm{A}$, et al. BMJ Case Rep Published Online First: [please include Day Month Year]. doi:10.1136/bcr-2017221913

\section{DESCRIPTION}

A 16-year-old healthy adolescent boy was referred to the paediatric endocrinology clinic because of multiple thyroid nodules detected by cervical ultrasound, in the context of cervical lymphadenopathies. There was no family history of thyroid disease. He denied recent infections, asthenia, weight loss, sweating, palpitations, mood or sleep disturbances, dysphagia or dysphonia. At physical examination, an enlarged, irregular and fibroelastic thyroid, with a predominant right lobe, was identified. The remaining examination was normal.

The analytical profile was thyroid stimulating hormone $(\mathrm{TSH})<0.01 \mathrm{uUI} / \mathrm{mL}$ (normal $0.5-4.8$ $\mathrm{uUI} / \mathrm{mL}$ ), free triiodothyronine (FT3) $7.27 \mathrm{pg} / \mathrm{mL}$ (normal $2.3-4.2 \mathrm{pg} / \mathrm{mL}$ ) and free thyroxine (FT4) $2.02 \mathrm{ng} / \mathrm{dL}$ (normal $0.8-2.3 \mathrm{ng} / \mathrm{dL}$ ). Thyroid antibodies were negative. Cervical ultrasound revealed an enlarged right thyroid lobe due to the presence of multiple mixed nodules with similar characteristics: the biggest one, $5 \mathrm{~cm}$ diameter, predominantly cystic with a peripheral ring of solid isoechoic parenchyma (figure 1A); the second characteristically mixed nodule, $2.2 \mathrm{~cm}$ diameter (figure 1B) and the third one, $1.2 \mathrm{~cm}$ diameter, predominantly solid with small cystic areas (figure 1C). Thyroid scintigraphy showed hyperactive multinodular goitre with predominance of autonomous hot nodules on the right lobe, suggestive of toxic multinodular goitre (TMNG) (figure $2 \mathrm{~A}-\mathrm{C}$ ). A fine needle aspiration biopsy of thyroid predominantly solid nodule, with ultrasound guidance, was performed to exclude malignancy but the cytological examination was non-diagnostic. The treatment options were discussed, with patient and family, and the surgical approach was followed due to the non-diagnostic result of biopsy and the high volume goitre. The patient started oral thiamazole to achieve euthyroidism and preparing for surgery.

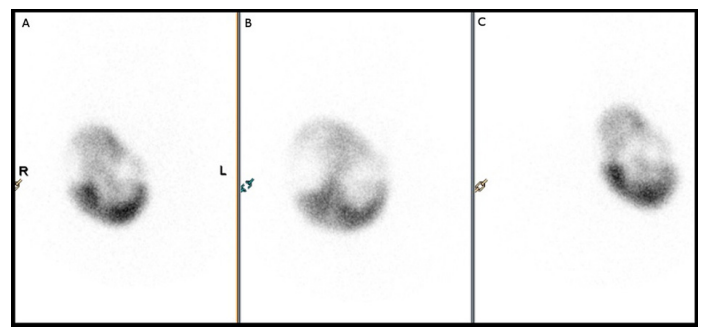

Figure 2 Thyroid scintigraphy showing hyperactive multinodular goitre with hot nodules dominant on the right lobe. Scintigraphic features suggestive of toxic multinodular goitre. (A) Anterior, (B) right anterior oblique and (C) left anterior oblique.

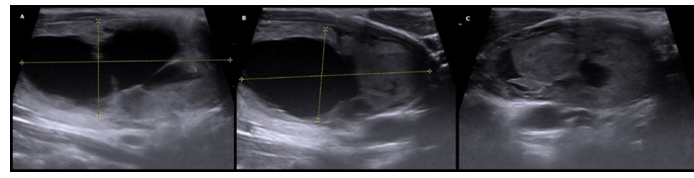

Figure 1 Cervical ultrasound revelling multiples nodules in the right thyroid lobe. (A) Predominantly cystic nodule, (B) characteristic mixed nodule and (C) predominantly solid nodule.

Thyroid nodules are a frequent incidental finding with an incidence between $9.4 \%$ and $27.0 \%{ }^{1}$ In contrast to adults, TMNG is an uncommon thyroid disease in paediatric age. The presence of hyperthyroidism determines the need for a definitive therapy in multinodular goitre, and a correct evaluation must be established before deciding between surgery or radioactive iodine. The diagnosis of TMNG (overt or subclinical) should always be excluded in patients with physical examination or ultrasound findings consistent with nodular thyroid disease. ${ }^{23}$

Contributors MR and HF were involved in the planning, conduct and conception of the work; acquisition, analysis and interpretation of data; manuscript writing; revision and final approval of the version. AA was involved in conception and design of the work; analysis and interpretation of data; critical review and final approval of the manuscript. OM was involved in conception, design and conduct the work; acquisition and interpretation of data; critical

\section{Learning points}

- Thyroid nodules are relatively common in adolescents, usually asymptomatic and often incidentally detected. While multinodular goitre has almost always a good prognosis, malignancy needs to be excluded and a large nodule increases its probability.

- The first line investigation should include a thyroid ultrasound to evaluate the nodules' characteristics and a thyroid stimulating hormone (TSH) determination. In the presence of a suppressed TSH, thyroid scintigraphy is indicated to differentiate between hyperfunctioning (hot) and hypofunctioning (cold) nodule.

- When hyperthyroidism is caused by an autonomous thyroid nodule, a definitive treatment is necessary such as radioactive iodine therapy or surgery. In children and adolescents, surgical resection must be considered in face of suspicious ultrasound findings, clinical presentation, nodule size $>4 \mathrm{~cm}$ and/or compressive symptoms. 
review and final approval of the manuscript. All authors contributed in the clinical orientation of the patient as well as article preparation.

Competing interests None declared.

Patient consent Guardian consent obtained.

Provenance and peer review Not commissioned; externally peer reviewed.

(c) BMJ Publishing Group Ltd (unless otherwise stated in the text of the article) 2017. All rights reserved. No commercial use is permitted unless otherwise expressly granted.

\section{REFERENCES}

1 Gharib H, Papini E, Garber JR, et al. American College of Endocrinology, and Associazione Medici Endocrinologi medical guidelines for clinical practice for the diagnosis and management of thyroid nodules - 2016 update. American Association of Clinical Endocrinologists 2016;22:1-60.

2 Francis GL, Waguespack SG, Bauer AJ, et al. Management guidelines for children with thyroid nodules and differentiated thyroid cancer. Thyroid 2015;25:716-59.

3 Muirhead S. Diagnostic approach to goitre in children. Paediatr Child Health 2001;6:195-9.

Copyright 2017 BMJ Publishing Group. All rights reserved. For permission to reuse any of this content visit

http://group.bmj.com/group/rights-licensing/permissions.

BMJ Case Report Fellows may re-use this article for personal use and teaching without any further permission.

Become a Fellow of BMJ Case Reports today and you can:

- Submit as many cases as you like

- Enjoy fast sympathetic peer review and rapid publication of accepted articles

- Access all the published articles

Re-use any of the published material for personal use and teaching without further permission

For information on Institutional Fellowships contact consortiasales@bmjgroup.com

Visit casereports.bmj.com for more articles like this and to become a Fellow 